\title{
The Effects of Tomato Concentration on Sensory and Chemical Properties of Jelly Drink
}

\author{
Setiarti Sukotjo ${ }^{1, *}$, Heru Irianto ${ }^{1}$, Shinta Leonita ${ }^{1}$, and Nita Yustika Sari ${ }^{1}$ \\ ${ }^{1}$ Department of Agro-Industrial Technology, InstitutTeknologi Indonesia, Tangerang Selatan \\ *Corresponding author.Email:teti.sukotjo@iti.ac.id
}

\begin{abstract}
Tomatoes, which have a limited shelf life must be processed further, one of which will be used as a jelly drink. In Indonesia, tomatoes are relatively inexpensive, but beverage products made from tomatoes are still limited. Jelly drinks are common among the general public, and they also serve as a hunger suppressant and a good source of fibers for digestion. Eucheuma cottonii seaweed is used as a gelling agent in the making of jelly drinks. Yet, the concentration of seaweed and tomato in the jelly drink formula was still unknown. This study aims to determine the effect of different concentrations of tomatoes on sensory properties of tomato jelly drinks, and to determine the most preferred tomato jelly drink by panellists for chemical properties analysis. The research consists of two phases, phase 1 (determining seaweed concentration) and phase 2 (determining tomato concentration). The sensory analysis, which included colour, aroma, texture, and taste, was used to determine the most preferred tomato jelly drink by the panelists. The chemical content is determined based on the most preferred tomato jelly drink by the panelists, that include vitamin $\mathrm{C}, \mathrm{pH}$, sucrose, and crude fiber analysis. This experiment used randomized block design (RBD) with one factorial, which was the concentration of tomatoes, consisting of three levels,54\%, 57\% and 60\%. The results showed that the concentration of tomato had significant effects on the score of the taste and texture of jelly drinks in sensory analysis, but had no significant effect on the score of the colour and the aroma of jelly drinks. The most preferred jelly drink was obtained from the tomato concentration of 57\%. The product had a colour score of 3.00 (normal - like); aroma score of 3.23 (normal - like); texture score of 3.47 (normal - like); taste score of 3.97 (normal - like), $\mathrm{pH} 4.37$; sucrose $31.35 \%$; crude fiber $3.28 \%$; and levels of vitamin C $23.76 \mathrm{mg} / 100 \mathrm{~g}$.
\end{abstract}

Keywords: Eucheuma cottonii seaweed, Jelly drink, Tomatoes.

\section{INTRODUCTION}

Jelly drinks are widely known and favored by people from children to adults. The market for jelly drink products is quite large. [1] Jelly drinks are not just ordinary drinks, but can also be consumed as a hunger delay. Jelly drinks are made from fruit juices with the addition of sugar, acid and gelling agent, so that a thick texture is formed in the form of a gel but can still be easily consumed with the help of a straw. Jelly drink is a drink in the form of a gel that can be consumed with the help of a straw, the texture is easily crushed but the gel form is still felt in the mouth.

One type of fruit that can be used as raw material for making jelly drinks is tomato. Tomato (Solanum lycopersicum L.) is one of the most widely cultivated agricultural commodities in Indonesia. According to The Central Statistics Agency and the Directorate General of
Horticulture, tomato production in Indonesia reached $1,020,333$ tons in the past year. [2] Although the level of tomato production is high, the types of processed tomato products are still few. In general, the processing of tomatoes in Indonesia is limited to being used as sauce, juice, or pasta. Tomatoes have a fairly high water content which causes the shelf life of tomatoes to be relatively short. Addition of tomato juice in the jelly drinks may affect its sensory parameters, specially the slightly sour taste. Tomatoes are known to contain nutrients that are beneficial to the human body, such as vitamin C. [3]

In addition to its fresh taste, tomatoes are also rich in nutrients such as carbohydrates, $\mathrm{Ca}, \mathrm{Fe}, \mathrm{Mg}$, vitamin $\mathrm{C}$, as well as vitamin $\mathrm{A}$, phosphate, potassium, and lycopene so that they can meet the nutritional needs of the community. Tomatoes contain lycopene which functions as an antioxidant that has the ability to provide protection from the risk of various diseases, including cancer and 
coronary heart disease. [4] Some research results show that lycopene is more easily absorbed by the body if the tomatoes are processed into processed tomato products.

To produce a jelly drink with a good gel structure, it is necessary to add a gelling agent. Jelly drinks that are currently circulating in the market use carrageenan powder as a gelling agent. The function of carrageenan powder as a gelling agent can be replaced by using seaweed and one of the is Eucheuma cottonii. [5]

The most common types of seaweed found in Indonesian waters are Gracilaria, Gelidium, Eucheuma, and Sargassum. [6] Of the various types of seaweed, which are cultivated, developed and widely traded in Indonesia are the caraginophyte species (among them Eucheuma spinosum, E. cottonii, E. edule, E. serra, and Eucheuma. spp) which are used as raw materials for various industries because it is a source of carrageenan (seaweed flour), agar and alginate. E.cottonii is one of the carrageenan-producing seaweeds. Carrageenan contains high fiber. Carrageenan is one of the gelling agents that is suitable to be used to form a gel structure in jelly drinks.

Despite having good nutritional content for the body and also high water content, tomato shelf life is relatively short. Therefore, further processing of tomatoes is needed in order to obtain a longer shelf life and at the same time increase the economic value of tomato commodities. To increase the shelf life of tomatoes, one of them is to make jelly drinks. The jelly drink also uses E.cottonii seaweed which acts as a gelling agent. The problem is that the exact formulation of the basic ingredients of tomatoes and E.cottonii seaweed is not known. The seaweed is used as a gelling agent in jelly drinks in order to get a jelly texture that is easily destroyed when consumed with the help of a straw, but the gel form is still felt in the mouth. E.cottonii seaweed was also used to make jelly drinks in previous research. [7]

The purpose of this research is to use tomatoes and seaweed E.cottonii in jelly drinks. This study aims to determine the effect of different concentrations of tomatoes on sensory properties of tomato jelly drinks, and to determine the most preferred tomato jelly drink by panellists for chemical properties analysis.

\section{MATERIALS AND METHOD}

The materials used in the production of tomato jelly drinks are tomatoes obtained from Bukit Indah Market, South Tangerang City; dried E.cottonii obtained from Lebak District, Banten; sugar; and water. Other materials are used for chemical analysis manufactured by Merck and Loba Chemie PVT.LTD (pH, sucrose, vitamin C, and crude fibers).
The research consisted of two phases, namely phase 1 , and phase 2 . Phase 1 was conducted to determine the concentration of E.cottonii seaweed which will be used as a reference in phase 2.Phase 2 was conducted to determine the concentration of tomatoes in jelly drink production. The jelly drink production process of this study refers to previous research. [8]

\subsection{Phase 1}

Phase 1 is a preliminary study to know the amount of E.cottonii added in jelly drinks. Variations of E.cottonii seaweed $(0.5 \% ; 2.5 \% ; 4.5 \%$; and $6.5 \%)$ will be tested. Descriptive analysis was done in phase 1 , by describing the characteristics of the tomato jelly drink based on sensory parameters. Sensory parameters were done based on colour, aroma, texture, and taste. The focus of Phase 1 was to know the right concentration of E.cottonii in order to get the similar texture of a commercial jelly drink. Commercial jelly drinks were only used as a comparison of texture. The preliminary research diagram is presented in Figure 3.1.

The study began with washing tomatoes using running water and the preparation of other materials. Washed tomatoes then weighed and cut into several parts. The tomatoes then are crushed in a blender with the addition of water and then filtered to get tomato juice.

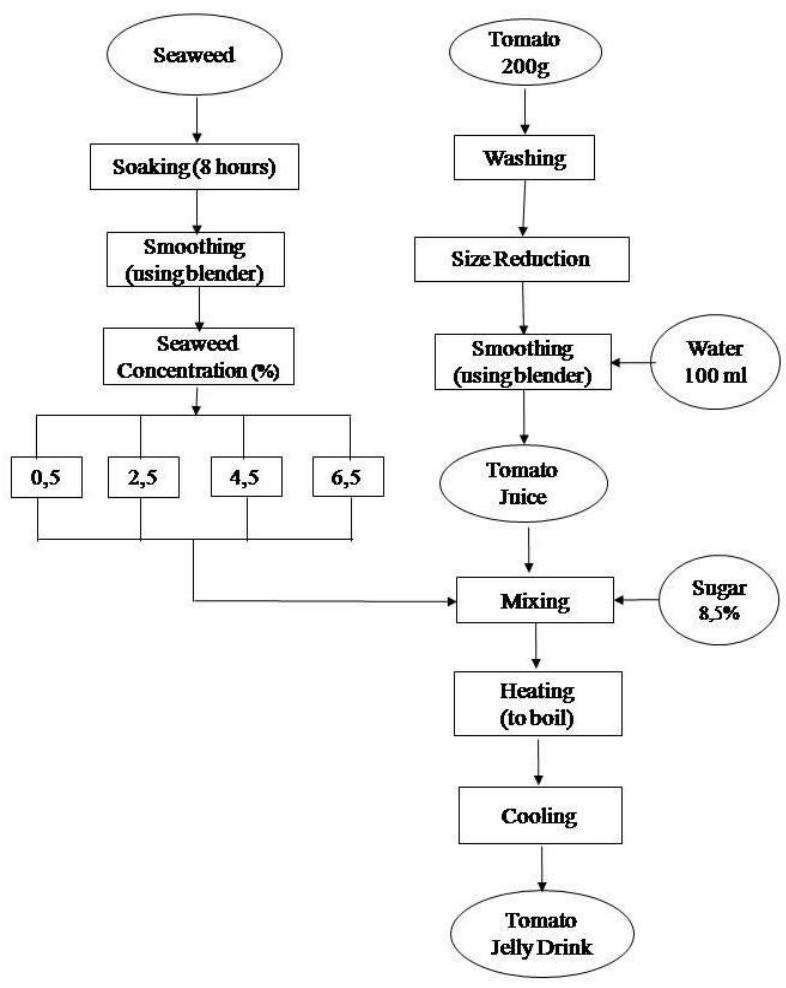

Figure 1. Phase 1 Research diagram. 
Furthermore, the seaweed is also crushed using a blender for a few seconds. The next process is mixing the ingredients, namely tomato juice, blended seaweed and sugar into a saucepan and then heated to a boil. After that, put it in a bottle to cool. The cooling process is carried out at room temperature to form a jelly drink. The different variations of tomato jelly drinks were described based on sensory analysis. Sensory analysis is carried out to provide quality assessment of the products using human senses as the main tool. The sensory analysis carried out was a preference test or hedonic test with assessments covering taste, aroma, colour, and texture.

\subsection{Phase 2}

In phase 2, the process of making jelly drinks was carried out based on the result of phase 1 . The concentration of seaweed used in the main study was based on the best seaweed concentration obtained from the research phase 1 . The process of making jelly drinks completely follows the stages of making jelly drinks in phase 1 . In this phase 2, variations in the tomato's concentration were $54 \%$; $57 \%$; and $60 \%$. The phase 2 research diagram can be seen in Figure 2.

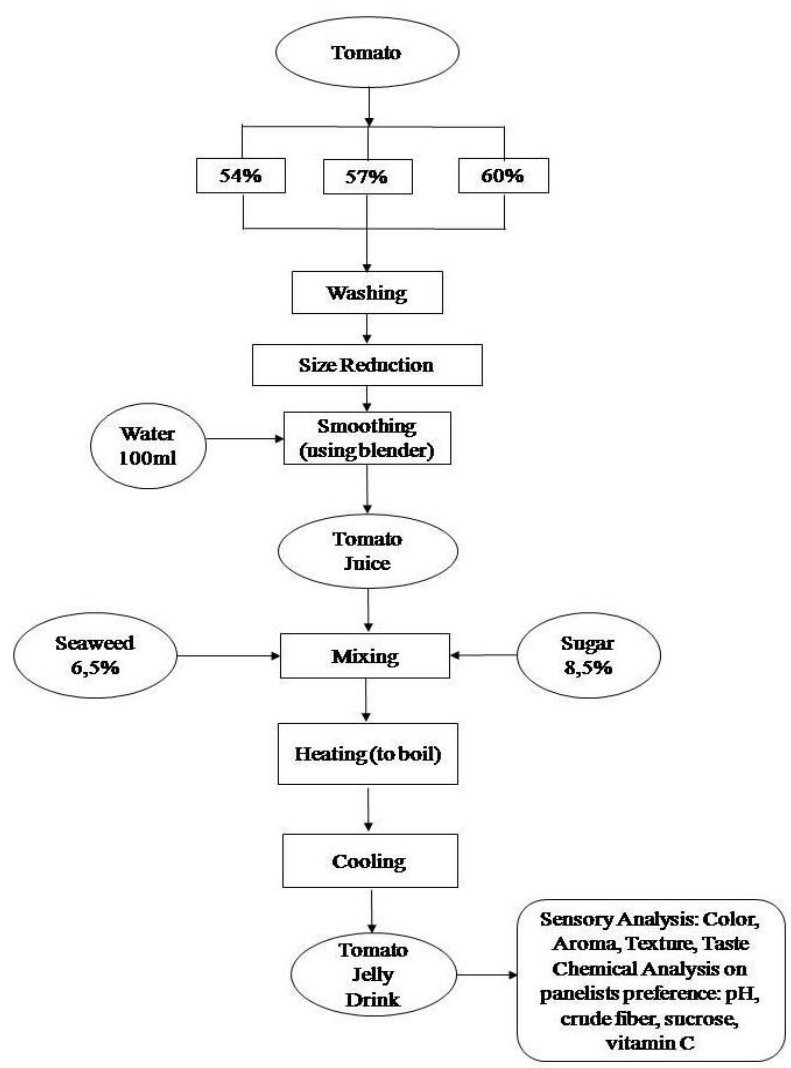

Figure 2.Phase 2 Research diagram
Sensory analysis was carried out by giving 3 (three) samples of jelly drink with 3 (three) digit random numbers to 30 panelists. The result was statistically analyzed using Anova. The experimental design used in this study was a Randomized Block Design. Further test, namely Duncan's Multiple Distance Test (DMRT) was done to determine the effect of the treatment.

As for chemical properties, $\mathrm{pH}$ analysis referred to SNI 606-6989 11-2004. [9] Sucrose analysis was based on SNI 01-2892-1992. [10] Crude fiber analysis referred to the SNI 01-2891-1992 method [11]. Vitamin C Analysis of tomato jelly drinks using the Iodometric method [12] .

Ethical clearance in this study was approved and provided by Komisi Etik Penelitian Kesehatan, Kementrian Kesehatan RI through Ethical Approval Letter No. LB.02.01/1/KE/31/203/2021 dated March 29, 2021.

\section{RESULTS AND DISCUSSION}

\subsection{Phase 1}

The results of sensory analysis which include colour, aroma, texture, and taste can be seen in Table 1. Based on the results of qualitative observations in the table, at a concentration of $0.5 \% ; 2.5 \%$; and $4.5 \%$ jelly drinks still had liquid texture, had not formed a gel and has a distinctive tomato taste. At a concentration of $6.5 \%$ the texture of the jelly drink was condensed, thick and yet easy to drink with the help of a straw. Due to the focus of phase 1 was to get the right amount of seaweed in the tomato jelly drink, it was necessary to compare the texture of tomato jelly drink with the commercial jelly drink. Unfortunately, commercial tomato jelly drinks are not available in the Indonesian market. Thus, commercial strawberry jelly drink was used as a comparison, for this research. The tomato jelly drink with $6.5 \%$ seaweed and commercial strawberry jelly drink showed similarity in its texture.

Table 1. The Result of Phase 1 Sensory analysis

\begin{tabular}{|c|l|l|l|l|}
\hline \multirow{2}{*}{$\begin{array}{c}\text { Seaweed } \\
\text { Concentration } \\
(\%)\end{array}$} & \multicolumn{4}{|c|}{ Sensory Parameter } \\
\cline { 2 - 5 } & Color & Aroma & Texture & Taste \\
\hline 0.5 & Red & Tomato & Liquid & Sour \\
\hline 2.5 & Red & Tomato & Liquid & Sour \\
\hline 4.5 & $\begin{array}{l}\text { Dark } \\
\text { Red }\end{array}$ & Tomato & Liquid & Sour \\
\hline 6.5 & $\begin{array}{l}\text { Dark } \\
\text { Red }\end{array}$ & $\begin{array}{l}\text { Tomato } \\
\text { seaweed }\end{array}$ & Condense & $\begin{array}{l}\text { Sweet } \\
+ \text { sour }\end{array}$ \\
\hline $\begin{array}{c}\text { Commercial } \\
\text { Jelly Drink }\end{array}$ & - & - & Condense & - \\
\hline
\end{tabular}


It can be explained that E.cottonii produce carrageenan, a hydrocolloid that is able to bind large amounts of water. Hydrocolloid is a polymer component that can dissolve in water, is able to form colloids, can thicken or form a gel from a solution [13]. Since $6.5 \%$ of seaweed concentration produced a good texture of jelly drink, then it will be used in phase 2

\subsection{Phase 2}

The result of sensory analysis in phase 2 of this study can be seen in Table 2, the tomato concentration of 54\% produced a jelly drink with a sweet taste and thick texture; thus, it was difficult to drink using straw. This is due to the use of a small concentration of tomatoes compared to other concentrations so as to produce a thicker texture when compared to other concentrations.

At a concentration of $57 \%$, tomatoes produce a texture that is not much different from a concentration of $60 \%$ which is less condensed and has a sweet and sour, a typical taste of tomatoes. The colour and aroma produced at each concentration are the same, which is dark red in colour and has a distinctive aroma of tomatoes and a slight seaweed.

The sensory analysis covering parameters of texture, taste, colour, and aroma was performed on 30 panelists. The average scores from sensory analysis are described in Table 3. The $57 \%$ concentration of tomato showed the highest overall score and there weren't any scores below 3.

Table 2.The Result of Phase 2 Sensory Parameters

\begin{tabular}{|c|c|c|}
\hline $\begin{array}{c}\text { Tomato } \\
\text { Concentration }\end{array}$ & $\begin{array}{c}\text { Appearance of } \\
\text { Tomato Jelly } \\
\text { Drink }\end{array}$ & Sensory Parameter \\
\hline $54 \%$ & & $\begin{array}{l}\text { Color :Dark Red } \\
\text { Aroma : Tomato } \\
\text { and slightly } \\
\text { seaweed } \\
\text { Texture :condensed } \\
\text { Taste :Sweet }\end{array}$ \\
\hline $57 \%$ & & $\begin{array}{l}\text { Color :Dark Red } \\
\text { Aroma }: \text { Tomato } \\
\text { and slightly } \\
\text { seaweed } \\
\text { Texture :less } \\
\text { condensed } \\
\text { Taste :Sweet-sour }\end{array}$ \\
\hline $60 \%$ & & $\begin{array}{l}\text { Color :Dark Red } \\
\text { Aroma : Tomato } \\
\text { and slightly } \\
\text { seaweed } \\
\text { Texture :less } \\
\text { condensed } \\
\text { Taste :Sweet-sour }\end{array}$ \\
\hline
\end{tabular}

Based on colour preference, the highest average yield was at $57 \%$ tomato concentration. Panelists did not like the colour of the jelly drink at a concentration of $54 \%$ because less concentration of tomatoes produced less red colour. The panellist found that the colour becomes less attractive.

As for the aroma, the highest average score was the use of $57 \%$ tomato concentration. At a concentration of $54 \%$, the panelists did not like the aroma produced because the distinctive aroma of seaweed was stronger than the aroma of tomatoes. Panelists tend to prefer the aroma at a concentration of $57 \%$ compared to a concentration of $60 \%$ because according to the panelists the distinctive aroma of tomatoes was not too strong. The distinctive aroma in tomatoes is due to the presence of terpenoids compounds. [14]

The use of different concentrations of tomatoes produces very significant different results on the texture of the jelly drink produced. Based on Figure 1, the highest average texture score for tomato jelly drinks was at tomato concentration of $57 \%$. Panelists did not like the texture of the jelly drink at a concentration of $54 \%$ because the resulting texture was too condensed. This is due to the least addition of tomato concentration and the addition of seaweed will make the texture more condense. Carrageenan from E. Cottonii is a hydrocolloid capable of binding large amounts of water [15]. Carrageenan in this case is able to bind the water contained in tomatoes, forming a gel, so that at lower concentrations of tomatoes the texture will be denser than at higher concentrations of tomatoes.

Based on the histogram, the panelists preferred the taste of jelly drinks at a concentration of $57 \%$. This can be seen from the results of the highest average test value. The taste preference for jelly drinks is at a concentration of $57 \%$. The use of different concentrations of tomatoes in jelly drinks has a very significant effect on the taste of the jelly drinks produced. Panelists tend to dislike the taste of jelly drinks at concentrations of $54 \%$ and $60 \%$. At a concentration of $60 \%$, the panelists did not like the taste of the jelly drink produced because the sour taste of tomatoes was stronger than at a concentration of $57 \%$.

According to the results obtained from the score value of sensory analysis, statistical analysis using ANOVA with one factor showed that there were no significant differences for colour and aroma, but different for texture and taste. Therefore, further test, DMRT was performed to determine the effect of the treatment (tomato concentration) on texture and taste. The result of DMRT is described using notation "a" and "b" on Table 3.

The data on Table 3 shows that according to the DMRT, there was significant difference in terms of texture and taste between jelly drinks using 54\% and 57\% tomato. It also shows there was a significant difference between jelly drink using $54 \%$ and $60 \%$ tomato. 
Table 3. Result of Statistical Analysis

\begin{tabular}{|c|c|c|c|c|}
\hline \multirow{2}{*}{$\begin{array}{c}\text { Tomato } \\
\text { Concentration }\end{array}$} & \multicolumn{4}{|c|}{ Average of Panelists Score } \\
\cline { 2 - 5 } & Color & Aroma & Texture & Taste \\
\hline $54 \%$ & 2,57 & 2,80 & $2,67^{\mathrm{b}}$ & $2,80^{\mathrm{b}}$ \\
\hline $57 \%$ & 3,00 & 3,23 & $3,47^{\mathrm{a}}$ & $3,97^{\mathrm{a}}$ \\
\hline $60 \%$ & 2,93 & 3,17 & $3,37^{\mathrm{a}}$ & $3,63^{\mathrm{a}}$ \\
\hline
\end{tabular}

Yet, there was no difference between a jelly drink using $57 \%$ and $60 \%$ tomato. Therefore, selection of the right tomato concentration is based on the efficient economical use of the materials, both in terms of costs and results obtained. Thus, using $57 \%$ of tomato is the chosen treatment, since it has more economical value.

Chemical analysis was carried out on the chosen treatment, which is using $57 \%$ of tomato. Chemical analysis carried out included analysis of $\mathrm{pH}$, crude fiber, sucrose, and vitamin $\mathrm{C}$.

The $\mathrm{pH}$ analysis carried out on the tomato fruit jelly drink refers to SNI 606-6989 11-2004. Based on the results of the analysis carried out on the tomato jelly drink, the $\mathrm{pH}$ of the tomato fruit jelly drink was 4.37 . This result was close to the $\mathrm{pH}$ of Pineapple jelly drink, that is 4.70 , but the $\mathrm{pH}$ of Belimbing Wuluh jelly drink was so low, that is 2.63. [16], [17] If the $\mathrm{pH}$ is too low, it can cause syneresis, causing the texture of the resulting jelly drink to be not sturdy [4]. On the other hand, if the $\mathrm{pH}$ is too high, it will produce a stiff gel. The optimum $\mathrm{pH}$ for gel formation is at $\mathrm{pH}$ 4-7 [18].

Sucrose content of tomato jelly drink corresponded to pineapple jelly drink, less than $2 \%$. [16] In tomato jelly drinks, the results showed that the sucrose content was $31.35 \%$, whereas pineapple jelly drink was $33.18 \%$. The sucrose is mainly used as a source of energy for the consumers.

Table 4. Chemical analysis of the Preferred Jelly Drink

\begin{tabular}{|l|c|c|c|c|}
\hline Parameters & $\begin{array}{c}\text { Tomato } \\
\text { Jelly } \\
\text { drink }\end{array}$ & $\begin{array}{c}\text { Pineapple } \\
\text { Jelly } \\
\text { Drink } \\
{[16]}\end{array}$ & $\begin{array}{c}\text { Belimbing } \\
\text { Wuluh } \\
\text { Jelly Drink } \\
{[17]}\end{array}$ & $\begin{array}{c}\text { Belimbing } \\
\text { Manis } \\
\text { Jelly Drink } \\
{[18]}\end{array}$ \\
\hline $\mathrm{pH}$ & 4.37 & 5.74 & 2.63 & $4.3-4.7$ \\
\hline $\begin{array}{l}\text { Crude } \\
\text { fiber (\%) }\end{array}$ & 3.28 & - & - & 0.006 \\
\hline $\begin{array}{l}\text { Sucrose } \\
(\%)\end{array}$ & 31.35 & 33.18 & - & - \\
\hline $\begin{array}{l}\text { Vitamin C } \\
(\mathrm{mg} / 100 \mathrm{~g})\end{array}$ & 23.76 & 24.89 & 9.62 & - \\
\hline
\end{tabular}

The crude fiber content produced in the tomato jelly drink is $3.28 \%$. Compare to other research, the crude fiber in tomato jelly drink was much higher than Belimbing Manis jelly drink which was only $0.006 \%$. [18] Crude fiber content in the tomato jelly drink increased due to the addition of E.cottonii seaweed. Besides functioning as a gelling agent, E. cottonii also functions as a good source of fiber for the human digestive tract.

The results of the vitamin $\mathrm{C}$ analysis in the tomato jelly drink was $23.76 \mathrm{mg} / 100 \mathrm{~g}$. The content of vitamin $\mathrm{C}$ in the tomato jelly drink was quite high compare to Belimbing wuluh jelly drink, which was $9.63 \mathrm{mg} / 100 \mathrm{~g}$. [17] Yet, compare to pineapple jelly drink, the content of vitamin $\mathrm{C}$ in tomato jelly drink is $1.13 \mathrm{mg} / 100 \mathrm{~g}$ lower. [16] If there is an addition of ingredients containing hydrocolloids in the manufacture of jelly drinks, more and stronger colloidal dispersion (double helix structure) will be formed so that it will inhibit the oxidation of vitamin $\mathrm{C}$ and can maintain vitamin $\mathrm{C}$. With a high double helix structure, vitamin $\mathrm{C}$ will be more protected.

Tomato jelly drinks have a low or acidic $\mathrm{pH}$. This result in accordance to Belimbing Manis Jelly drink, which had are range of 4.3-4.7. [18] Belimbing wuluh jelly drink showed lower $\mathrm{pH}$, while pineapple jelly drink showed higher $\mathrm{pH}$ compare to tomato jelly drink. [17] [16] Vitamin C is basically an acid with the chemical name ascorbic acid. The oxidation of ascorbic acid or vitamin $\mathrm{C}$ can be inhibited by acidic conditions or by low temperatures. [19] Generally, vitamin $\mathrm{C}$ has a $\mathrm{pH}$ range of 2 to 4 . The tomato jelly drink has a $\mathrm{pH}$ of 4.37 , so in this condition the vitamin $\mathrm{C}$ content is relatively high.

\section{CONCLUSION}

The preferred product according to panelists was tomato jelly drinks using seaweed concentration of $6.5 \%$ and tomatoes concentration of $57 \%$. The average panelists score for the product in color preference was 3.00 (ordinary), aroma preference was 3.23 (ordinary likes); texture preference was 3.47 (normal - like), and taste preference was 3.97 (ordinary - like). Chemical properties of the preferred product were as follows: $\mathrm{pH}$ 4.37, sucrose content $31.35 \%$, crude fiber content of $3.28 \%$, and vitamin C content of $23.76 \mathrm{mg} / 100 \mathrm{~g}$.

\section{ACKNOWLEDGMENTS}

The team would like to thank LPKT- ITI for providing the research funds and to the Department of Agro-Industrial Technology for providing the research facilities. Thanks to all colleagues for the encouragement and constructive ideas. Appreciation goes to students who support and make this research possible. 


\section{REFERENCES}

[1] Hartati FK, Djauhari AB. Pengembangan produk jelly drink temulawak (Curcuma xanthorrhiza Roxb.) sebagai pangan fungsional. Jurnal Teknik Industri HEURISTIC 14(2), 2017, pp. 107-122.

[2] The Central Statistics Agency and the Directorate General of Horticulture. Statistik Tanaman Sayuran dan Buah-Buahan Semusim Indonesia. Jakarta: Badan Pusat Statistik Republik Indonesia, 2019.

[3] Sari LDA, Ningrum RS, Ramdani AH, Kurniawati E. Kadar vitamin C buah tomat (Lycopersicum esculentum Mill) tiap fase kematangan berdasar hari setelah tanam. Jurnal Farmasi Dan Ilmu Kefarmasian Indonesia 8(1), 2021, pp. 74-82.

[3] Dewandari KT, Kailaku SI, Sunarmani. Perubahan kandungan likopen dan kualitas pasta tomat selama proses pengolahan. 2009, Jurnal Pascapanen 6(2), 2009, pp. 102-107.

[4] Hotchkiss S, Brooks M, Campbell R, Philp K, Trius A, The Use of Carrageenan Food in: Pareira L, editor, Carrageenans, Nova Science Publishers, Inc., 2016. p. 229-43.

[5] Direktorat Jenderal Perikanan Budidaya, Kementerian Kelautan dan Perikanan, Sentra Produksi Total Rumput Laut cottonii Indonesia, Jakarta: Kementerian Kelautan dan Perikanan, 2013.

[6] Akrim D, Dirawan GD, Rauf BA. Perkembangan budidaya rumput laut dalam meningkatkan perekonomian masyarakat pesisir di Indonesia. UNM Environmental Jurnal 2(2), 2019, pp. 52-56. Available from https://creativecommons.org/licenses/by-nc/4.0/

[7] Trilaksani W, Setyaningsih I, Masluha D. Formulasi Jelly Drink berbasis Rumput Laut Merah dan Spirulina platensis. JPHPI 18(1), 2015, pp. 74-82. Available from: https://journal.ipb.ac.id/index.php/jphpi DOI: 10.17844/jphpi.2015.18.1.74

[8] Gani YF, Suseno TIP, Surjoseputro S. Perbedaaan konsentrasi karagenan terhadap sifat fisikokimia dan organoleptik jelly drink rosella-sirsak. Jurnal Teknologi Pangan dan Gizi 13920, 2014, pp. :87-93.

[9] Badan Standarisasi Nasional. Cara uji derajat keasaman $(\mathrm{pH})$ dengan menggunakan alat $\mathrm{pH}$ meter (SNI 06-6989 11-2004). Jakarta: Badan Standarisasi Nasional, 2004.

[10] Badan Standarisasi Nasional. Cara uji gula (SNI 012892-1992). Jakarta: Badan Standarisasi Nasional, 1992.
[11] Badan Standarisasi Nasional. Cara uji serat kasar. (SNI 01-2891-1992). Jakarta: Badan Standarisasi Nasional, 1992.

[12] AOAC. Official Methods of Analysis of The Association of Analytical Chemist.,Washington DC: AOAC, 1995.

[13] Herawati H. Potensi hidrokoloid sebagai bahan tambahan pada produk pangan dan non-pangan bermutu. Jurnal Litbang Pertanian, 37(1), 2018, pp. $17-25$.

[14] Novelina, Nazir N, Adrian, MR. The improvement of lycopene availability and antioxidant activities of tomato (Lycopersicum esculentum, Mill) jelly drink. Agriculture and Agricultural Science Procedia 9, 2016, pp. 328 - 334. Available from: https://www.researchgate.net/publication/2958331 81 The Improvement Lycopene Availability and Antioxidant Activities of Tomato_Lycopersicu $\underline{\text { m_Esculentum_Mill_Jelly_Drink }}$

[15] Khalil HPSA, Lai TK, Tye YY, Rizal S, Chong EWN, Yap SW, A review extraction of seaweed hydrocolloids: properties and application, eXPRESS Polymer Letter 12(4), 2018, pp. 296-317. Available from: https://doi.org/10.3144/expresspolymlett.2018.27

[15] Tiwang YC, Samual MF, Oessoe YYE. Pengaruh konsentrasi sukrosa terhadap kualitas Jelly Drink nanas (Ananas comosus L) Merr. Journal of Food Research 1(1), 2021, pp. 35-43. Available from https://ejournal.unsrat.ac.id/index.php/srjfr/index

[16] Agustin F, Putri WDR. Pembuatan Jelly Drink Averrhoa bilimbi L. (Kajian proporsi belimbing wuluh: air dan konsentrasi karagenan). Jurnal Pangan dan Agroindustri 12(3),2014, pp. 1-9.

[17] Aini MAQ, Rahmi A, Sutoyo. Syarat mutu ( Kajian kombinasi konsentrasi sari buah belimbing manis dan karagenan pada pembuatan jelly drink belimbing manis. Jurnal Teknologi Pertanian Andalas 23(2), 2019, pp. 158-164.

[18] Novelina, Nazir N, Adrian MR. The improvement of lycopene availability and antioxidant activities of tomato (Lycopersicum esculentum, Mill) jelly drink. Agriculture and Agricultural Science Procedia 9, 2016, pp. 328-334.

[19] Winarno FG, Rahayu S, Kimia pangan dan gizi. Jakarta:Sinar Pustaka Harapan;1997. 